\title{
US health bill promises changes for biomedical researchers
}

总

The historic health-care bill that passed the US House of Representatives on 21 March includes several lesser-known provisions that will significantly affect biomedical researchers, teaching hospitals and the biotechnology industry.

The final legislation, which is expected to become law, would establish a new competitive grant programme at the National Institutes of Health (NIH). Called the Cures Acceleration Network (CAN), this provision was written into the law by Senator Arlen Specter (Democrat, Pennsylvania). It will authorize as much as US $\$ 500$ million annually for speeding the translation of basic discoveries into treatments, through individual awards of up to \$15 million per year. The CAN would be separate from an already existing NIH programme called Clinical and Translational Science Awards, which has a budget of roughly $\$ 483$ million in 2010 .

The CAN programme comes without the guarantee of new money, and how it will be funded remains unclear. Advocates for basic research are worried that if Congress does not increase the NIH budget, funding might be pulled from its flagship, investigatorinitiated R01 awards.

"There has already been a long slide or stagnation in the funding of the gold standard: the R01," says Mark Lively, president of the Federation of American Societies for Experimental Biology in Bethesda, Maryland. "We would be concerned that any mandate that would require the NIH to move money to the $\mathrm{CAN}$ could very well come at the cost of losing still more R01s."

Another provision in the bill will expose relationships between physician researchers and the medical industry. From 2013, companies will have to report to the Department of Health and Human Services every payment in cash, stock or kind of more than $\$ 10$ they make to physicians and to teaching hospitals, in gifts, entertainment, and for services such as consulting and public speaking. The department will post the payments in a publicly accessible database.

Companies that produce biologics complicated and expensive protein-based drugs - do well out of the legislation. The new law will effectively guarantee

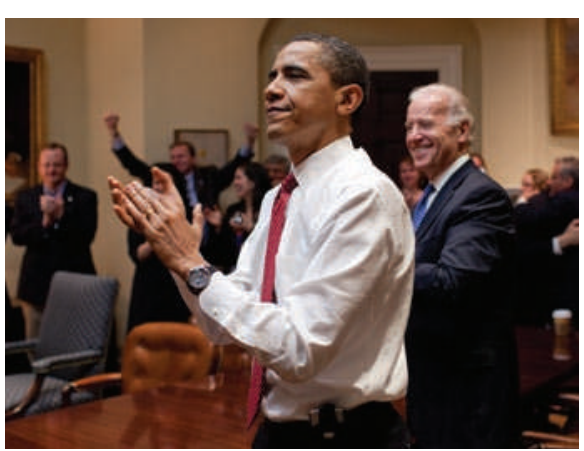

Barack Obama applauds the health reform bill.

12 years of exclusive market access for makers of brand-name biologics before generic competitors can produce 'biosimilars', which mimic the original molecules.

This provision is part of language that establishes a regulatory path by which makers of biosimilars can win marketing approval from the Food and Drug Administration (FDA). The European Union opened just such a regulatory path in 2005; the European Medicines Agency has since approved 14 such drugs.

When Congress considered similar biologics legislation in 2008, the Congressional Budget Office estimated that its provisions for FDA approval of biosimilars would save about $\$ 25$ billion over ten years by driving down prices of biologic drugs.

Jim Greenwood, the president and chief executive of the Biotechnology Industry Organization, a lobby group based in Washington DC, said that the law "will lead to new and improved treatments, cures and cost-savings for patients, while driving job growth in our industry".

But Kathleen Jaeger, president of the Generic Pharmaceutical Association, also based in Washington DC, lamented the pathway's "excessive and unprecedented market exclusivity protections for the brand industry". Generics makers and their congressional allies had sought to limit brand-name exclusivity to six years.

\section{Correction}

The News story 'Science survives Canadian budget' (Nature 464, 153; 2010) gave the wrong affiliation for Paul Dufour: he is head of the science-policy consultancy Paulicyworks based in Gatineau, Quebec. 